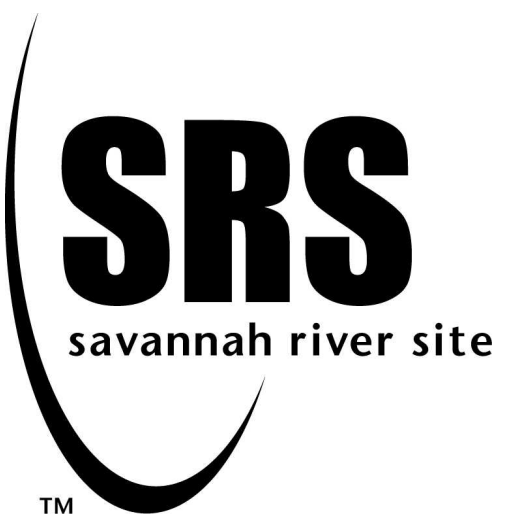

\title{
Waste Characterization of Polymeric Components Exposed to Tritium Gas
}

\author{
Elliot A. Clark
}

Publication Date: 15 February 2008

\section{Savannah River National Laboratory Washington Savannah River Company Savannah River Site Aiken, South Carolina}

This document was prepared in connection with work done under Contract No. DE-AC09-96SR18500 with the U.S. Department of Energy. By acceptance of this document, the publisher and/or recipient acknowledges the U.S. Government's right to retain a nonexclusive, royalty-free license in and to any copyright covering this document, along with the right to reproduce and authorize others to reproduce all or part of the copyrighted material.

\section{WASHINGTON SAVANNAH RIVER COMPANY}

The WSRC Team: Washington Savannah River Company LLC • Bechtel Savannah River, Inc. • BNG America Savannah River Corporation • BWXT Savannah River Company • CH2 Savannah River Company 


\section{DISCLAIMER}

This report was prepared as an account of work sponsored by an agency of the United States Government. Neither the United States Government nor any agency thereof, nor any of their employees, nor any of their contractors, subcontractors or their employees, makes any warranty, expressed or implied, or assumes any legal liability or responsibility for the accuracy, completeness, or any third party's use or the results of such use of any information, apparatus, product, or process disclosed, or represents that its use would not infringe privately owned rights. Reference herein to any specific commercial product, process, or service by trade name, trademark, manufacturer, or otherwise, does not necessarily constitute or imply its endorsement, recommendation, or favoring by the United States Government or any agency thereof or its contractors or subcontractors. The views and opinions of authors expressed herein do not necessarily state or reflect those of the United States Government or any agency thereof. 


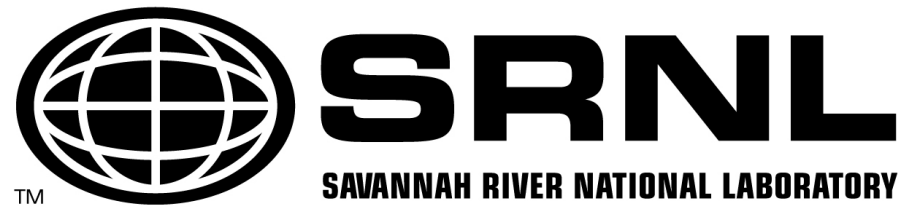

\title{
MATERIALS SCIENCE AND TECHNOLOGY
}

15 February 2008

\author{
Keywords: Tritium \\ Radioactive Waste \\ Characterization \\ Polymers
}

Retention - Permanent

\section{Waste Characterization of Polymeric Components Exposed to Tritium Gas}

\author{
Elliot A. Clark \\ Materials Science and Technology
}

Savannah River National Laboratory, Aiken, South Carolina 29808

\section{Washington Savannah River Company}

Prepared for the U. S. Department of Energy under Contract DE-AC09-96SR18500 


\section{APPROVALS}

E.A. Clark, AUTHOR

Date: -

Materials Compatibility and Joining Technology Group MATERIALS SCIENCE AND TECHNOLOGY

RL. Rabun, CUSTOMER

Date: DEFENSE PROGRAMS ENGINEERING

P.S. Korinko, TECHNICAL REVIEWER MATERIALS SCIENCE AND TECHNOLOGY

M.E. Dup'nt, ACTING MANAGER

Materials Compatibility and Welding Technology Group MATERIALS SCIENCE AND TECHNOLOGY

N.C. Iyer, DIRECTOR $U$

Date:

Date:

\section{Date:-}

MATERIALS SCIENCE AND TECHNOLOGY 


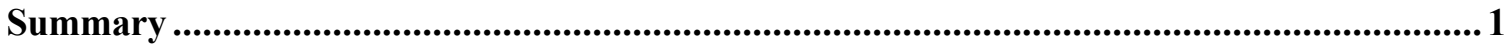

Background ................................................................................................................................. 1

Review of Mound Laboratory Study ......................................................................................... 1

Corroborative SRNL Study ......................................................................................................... 2

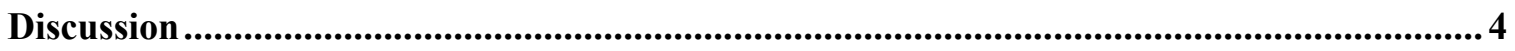

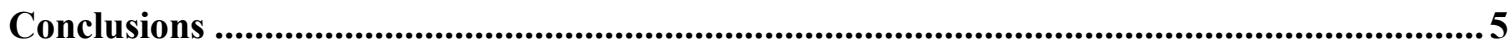

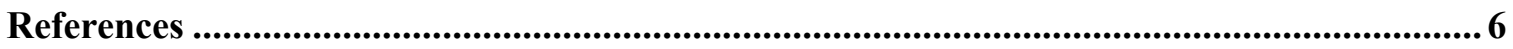

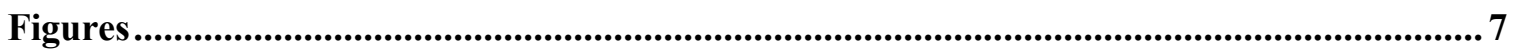

\section{TABLES}

I. Exposure time, total pressure, percent protium for UHMW-PE ......................................... 3

II. Exposure time, total pressure, percent protium for PTFE.................................................. 3

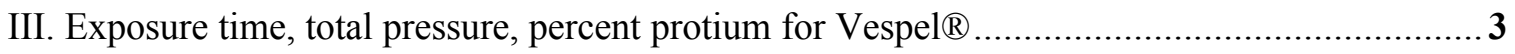

IV. Polymer volume, free volume, density, mass of samples for SRNL study ........................... 4

\section{FIGURES}

1. Total pressure in exposure containers for UHMW-PE, PTFE, and Vespel ${ }^{\circledR}$............................ 7

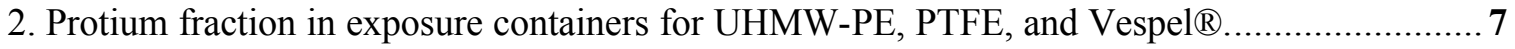

3. Curies tritium per unit polymer volume for Mound and SRNL studies .................................8 
PAGE INTENTIONALLY BLANK 


\title{
Waste Characterization of Polymeric Components Exposed to Tritium Gas
}

\author{
Elliot A. Clark \\ Materials Science and Technology \\ Savannah River National Laboratory
}

\begin{abstract}
$\underline{\text { Summary }}$
A recent independent review led to uncertainty about the technical basis for characterizing the residual amount of tritium in polymer components used in the Savannah River Site Tritium Facilities that are sent for waste disposal. A review of a paper published in the open literature firmly establishes the basis of the currently used characterization, $10 \mathrm{Ci} / \mathrm{cc}$. Information provided in that paper about exposure experiments performed at the DOE Mound Laboratory allows the calculation of the currently used characterization. These experiments involved exposure of high density polyethylene (HD-PE) to initially $1 \mathrm{~atm}$ tritium gas. In addition, a review of recent research at the Savannah River Site not only further substantiates this characterization, but also establishes its use for ultra-high molecular weight polyethylene (UHMW-PE), polytetrafluoroethylene (PTFE, a trade name is Teflon $\left.{ }^{\circledR}\right)$, and Vespel ${ }^{\circledR}$ polyimide. $10 \mathrm{Ci} / \mathrm{cc}$ tritium is a representative characterization for any type of polymer components exposed at ambient temperature and at approximately $1 \mathrm{~atm}$. tritium gas.
\end{abstract}

\section{Background}

A recent independent review of documentation related to disposing of solid polymer components used for processing tritium at the Savannah River Site questioned the technical basis for the characterization that has been used for their disposal as radioactive waste. A critical review was requested to validate the characterization of residual tritium in polymer parts disposed of as solid waste.

\section{Review of Mound Laboratory Study}

A study at the former Mound Laboratory exposed high-density polyethylene (HD-PE) to initially 1 atm. of tritium gas at about $23^{\circ} \mathrm{C}$. for 167 days [1]. Changes of the gas composition and of the molecular structure of the HD-PE were monitored by Raman infrared spectroscopy, and the total pressure in the closed sample manifold was monitored by a pressure transducer. In the text of the paper [1], the following data are presented:

Cell free volume $=5.65 \mathrm{cc}$ (volume available for a gas to fill within the closed system);

HD-PE sample volume $=0.115 \mathrm{cc}$;

HD-PE sample mass $=0.109 \mathrm{~g}$;

HD-PE density $=0.948 \mathrm{~g} / \mathrm{cc}$.

Review of Figure 2. in the paper gives, after 167 days exposure: 
Tritium pressure reduced by sample absorption $=0.048 \mathrm{~atm}$;

Tritium pressure reduction by glass cell absorption $=0.03 \mathrm{~atm}$.

The author estimated the pressure reduction by glass cell absorption by calculating the amount of protium that "should" have been produced if the G-value of hydrogen production in HD-PE is that published for $\gamma$ ray irradiation, accounting for the difference as being absorbed by the glass cell wall.

To realistically and conservatively estimate the amount of tritium in the HD-PE, the total pressure loss of tritium, $0.048+0.03$ atm or 0.078 atm. is used- no credit is taken for that amount of gas thought absorbed by the cell. Using the Ideal Gas Law $(\mathrm{pV}=\mathrm{nRT})$ :

Moles tritium into HD-PE $=$

$(0.078 \mathrm{~atm}$ lost $) *(5.65 \mathrm{cc}$ free volume $) / 296 \mathrm{kelvins} / 82.05$ [atm-cc/g-mol/K]

or $1.81 * 10^{-5}$ mole $\mathrm{T}_{2} .(82.05$ [atm-cc/g-mol/K] is the gas constant $\mathrm{R}$ for the units employed here.) The specific activity of tritium is $58,023 \mathrm{Ci} / \mathrm{mol} \mathrm{T}_{2}$ [2], so $1.81 * 10^{-5} \mathrm{~mole}_{2}$ is $1.05 \mathrm{Ci}$. Dividing by the sample volume (above), the amount of tritium absorbed in the HD-PE per unit volume is 9.16 $\mathrm{Ci} / \mathrm{cc}$. This is the basis of the currently used, slightly more conservative, $10 \mathrm{Ci} / \mathrm{cc}$ in the SRS Tritium Facilities.

\section{Corroborative SRNL Study}

Over the past several years, a study by the Savannah River National Laboratory exposed samples of ultrahigh molecular weight polyethylene (UHMW-PE), polytetrafluoroethylene (PTFE, Teflon ${ }^{\circledR}$ is a trade name), and Vespel ${ }^{\circledR}$ polyimide to initially one atmosphere tritium gas in closed stainless steel containers, having total internal volume $21 \mathrm{cc}$ at ambient temperature $[3,4]$. Exposure times varied from 52 to 826 days (2.3 years). Protium was produced in great quantities in containers of UHMW-PE up to about 9.2 atm at 826 days exposure, the total pressure dropped in the PTFE containers, and although the pressure of the Vespel ${ }^{\circledR}$ containers was relatively constant, the gas became about $50 \%$ protium, due to isotope exchange with protium in the polymer (Figs. 1, 2). The significant protium production in the UHMW-PE experiments is expected based on the literature results of irradiation of polyethylene [5], and compares well with that found in the Mound study. The reduction of pressure for PTFE is explained by the formation of TF molecules that adhere to the surface of the container.

The data plotted in Figs. 1 and 2 are tabulated in Tables I, II, and III. The tritium data is found by subtracting the protium data from $100 \%$. 


\begin{tabular}{|r|r|r|}
\hline \multicolumn{1}{l|}{$\begin{array}{l}\text { Exposure } \\
\underline{\text { time (d) }}\end{array}$} & \multicolumn{1}{l|}{$\begin{array}{l}\text { Pressure } \\
\text { (torr) }\end{array}$} & \multicolumn{1}{l|}{ \% H $_{2}$} \\
\hline 0 & 760 & $0 \%$ \\
\hline 52 & 831 & $32 \%$ \\
\hline 108 & 1291 & $63 \%$ \\
\hline 185 & 1979 & $62 \%$ \\
\hline 276 & 2777 & $85 \%$ \\
\hline 377 & 3693 & $90 \%$ \\
\hline 568 & 3029 & $90 \%$ \\
\hline 826 & 6957 & $91 \%$ \\
\hline
\end{tabular}

Table I. Exposure time, total gas pressure, and percent $\mathrm{H}_{2}$ (protium) in gas for UHMW-PE [3,4]

\begin{tabular}{|r|r|r|}
\hline \multicolumn{1}{l|}{$\begin{array}{l}\text { Exposure } \\
\underline{\text { time (d) }}\end{array}$} & \multicolumn{1}{l|}{$\begin{array}{l}\text { Pressure } \\
\text { (torr) }\end{array}$} & \multicolumn{1}{c|}{$\mathbf{H}_{\mathbf{2}}$} \\
\hline 0 & 760 & $0 \%$ \\
\hline 48 & 642 & $2 \%$ \\
\hline 108 & 639 & $24 \%$ \\
\hline 185 & 751 & $1 \%$ \\
\hline 276 & 596 & $0 \%$ \\
\hline 377 & 551 & $5 \%$ \\
\hline 568 & 560 & $1 \%$ \\
\hline 826 & 443 & 0 \\
\hline
\end{tabular}

Table II. Exposure time, total pressure, and percent $\mathrm{H}_{2}$ (protium) in gas for PTFE [3,4].

\begin{tabular}{|c|c|c|}
\hline$\frac{\text { Exposure }}{\text { time (d) }}$ & $\begin{array}{l}\text { Pressure } \\
\text { (torr) }\end{array}$ & $\% \mathrm{H}_{2}$ \\
\hline 0 & 760 & $0 \%$ \\
\hline 108 & 687 & $50 \%$ \\
\hline 112 & 687 & $47 \%$ \\
\hline 185 & 715 & $35 \%$ \\
\hline 276 & 602 & $54 \%$ \\
\hline 377 & 649 & $\# \mathrm{~N} / \mathrm{A}$ \\
\hline 568 & 811 & $44 \%$ \\
\hline 826 & 714 & $41 \%$ \\
\hline
\end{tabular}

Table III. Exposure time, total gas pressure, and percent $\mathrm{H}_{2}$ (protium) in gas for Vespel ${ }^{\circledR}$ polyimide $[3,4]$. 
Other quantities measured during these experiments were (Table IV):

\begin{tabular}{|l|l|l|l|l|}
\hline & UHMW-PE & PTFE & Vespel & Units \\
\hline $\begin{array}{l}\text { Average Polymer } \\
\text { volume }\end{array}$ & 2.3 & 1.8 & 2.1 & $\mathrm{cc}$ \\
\hline Average Free volume & 18.7 & 19.2 & 18.9 & $\mathrm{cc}$ \\
\hline Density & 0.91 & 2.20 & 1.4 & $\mathrm{~g} / \mathrm{cc}$ \\
\hline Average Mass & 2.07 & 3.89 & 2.94 & $\mathrm{~g}$ \\
\hline
\end{tabular}

Table IV. Polymer volume, free volume, density, and mass of samples for SRNL study.

Similar to the analysis presented above for the Mound data, the tritium activity within the polymers can be calculated. The temperature was assumed to be 296 kelvins $\left(23^{\circ} \mathrm{C}\right.$.).

First, the number of moles of tritium in the gas was found using the Ideal Gas Law (gas constant $\mathrm{R}=62,400$ torr-cc $/(\mathrm{g}-\mathrm{mol} / \mathrm{K}))$ :

Moles Tritium in Gas (time $\mathrm{t})=(1$ - protium fraction $) *$ pressure $($ torr $) *$ free volume $(\mathrm{cc}) / 296$ kelvins/62,400 [torr-cc/g-mol/kelvin].

Next, the amount of tritium in the polymer was found using:

Moles Tritium in Polymer $=($ Moles Tritium in gas at $\mathrm{t}=0) *$ DecayFactor - moles tritium in gas at time $\mathbf{t}>0$,

in which

DecayFactor $=e^{- \text {time }(d) * \ln (2) / 365.24 / 12.38}$

accounts for the decay of the original amount of tritium gas put in the container. The time is given in days and the half life of tritium is 12.38 years. The initial pressure of all exposure experiments was 760 torr.

Results of these calculations are remarkably consistent with the earlier study (Fig.3). A value of 10 $\mathrm{Ci} / \mathrm{cc}$ reliably and conservatively describes the amount of tritium "absorbed" by all the polymers examined. As discussed above, it is believed that the net drop in pressure in the PTFE containers results from TF $\left({ }^{3} \mathrm{HF}\right)$ formation and subsequent coating of the container and sample walls.

\section{$\underline{\text { Discussion }}$}

This result can be directly applied to polymers exposed to gaseous tritium near ambient temperature and at tritium partial pressures near one atmosphere. For parts exposed at much lower tritium partial 
pressure, the $10 \mathrm{Ci} / \mathrm{cc}$ value can be reduced by ratio of the tritium partial pressure in the gas. This is because the solubility of simple (low molecular weight) molecules in polymers is a linear function of the partial pressure [6]. For example, if a part is exposed to one atmosphere total pressure at $0.1 \%$ concentration tritium, the tritium partial pressure is $0.001 \mathrm{~atm}$ and characterization would be 0.01 $\mathrm{Ci} / \mathrm{cc}$ tritium in the polymer. Likewise, for parts exposed at elevated pressure, the result would increase by the partial pressure of tritium. For parts mainly exposed to low partial pressure tritium but are occasionally exposed to high partial pressure for relatively short times, the overall amount of tritium in the polymer would be adequately described by the lower partial pressure value.

This analysis does not apply to so-called "job control waste" or other items that become tritium contaminated by contacting moveable tritiated particulate contamination. This analysis only applies to polymer components absorbing tritium by contacting gaseous tritium for relatively long times.

\section{Conclusions}

Analysis of results of two experimental studies, at Mound Laboratory [1] and at the Savannah River Site $[3,4]$, reveals that for four different polymers, HD-PE, UHMW-PE, PTFE, and Vespel ${ }$, exposed to tritium gas for as long as two years, a relatively consistent value for the uptake of tritium by the polymers of $10 \mathrm{Ci} / \mathrm{cc}$ is observed. This analysis supports the current characterization of tritium-gas-exposed polymer components at the Savannah River Site Tritium Facilities, and shows it can be applied to different polymers for relatively long time exposures, far beyond the time of exposure during the earlier Mound study. 


\section{$\underline{\text { References }}$}

1. J.T. Gill, "Interaction of Polyethylene and Tritium Gas as Monitored by Raman Spectroscopy", Fusion Technology Vol. 8, pp 2318-2329 (Sept. 1985).

2. "DOE Handbook- Tritium Handling and Safe Storage", DOE-HDBK-1299-99, US Department of Energy, Washington DC 20585 (http://www.hss.doe.gov/NuclearSafety/techstds/standard/hdbk1129/hdbk1129.pdf), Appendix A (1999).

3. E.A. Clark and K.L. Shanahan, "Effects of Tritium Exposure on UHMW-PE, PTFE, and Vespel ${ }^{\circledR}$ ", Report WSRC-STI-2006-00049, Savannah River National Laboratory, Washington Savannah River Company, DOE Savannah River Site, Aiken SC (31 May 2006).

4. E.A. Clark and K.L. Shanahan, "Effects of Tritium on UHMW-PE, PTFE, and Vespel® polyimide", Fusion Science and Technology, Volume 52, Number 4, pp 1007-1011 (November 2007).

5. D.C. Phillips, "Effects of radiation on polymers", Materials Science and Technology, vol. 4 pp 85-91 (January 1988).

6. J. Crank, G.S. Park, eds., Diffusion In Polymers, Academic Press, London, pp. 5, 41-42 (1968). 


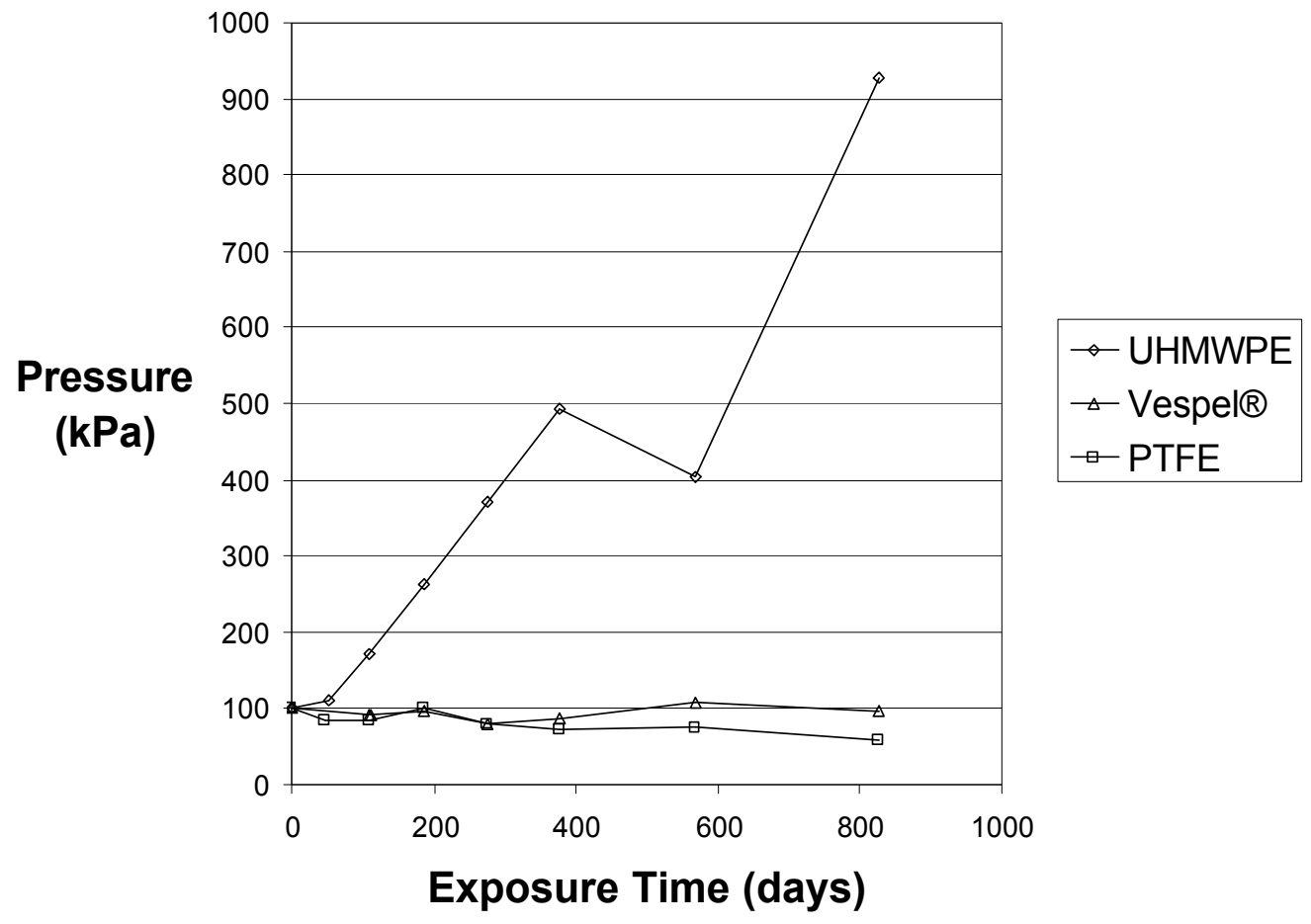

Fig. 1. Total pressure in exposure containers at end of exposure, as function of exposure time. UHMW-PE, Vespel®, PTFE as marked.

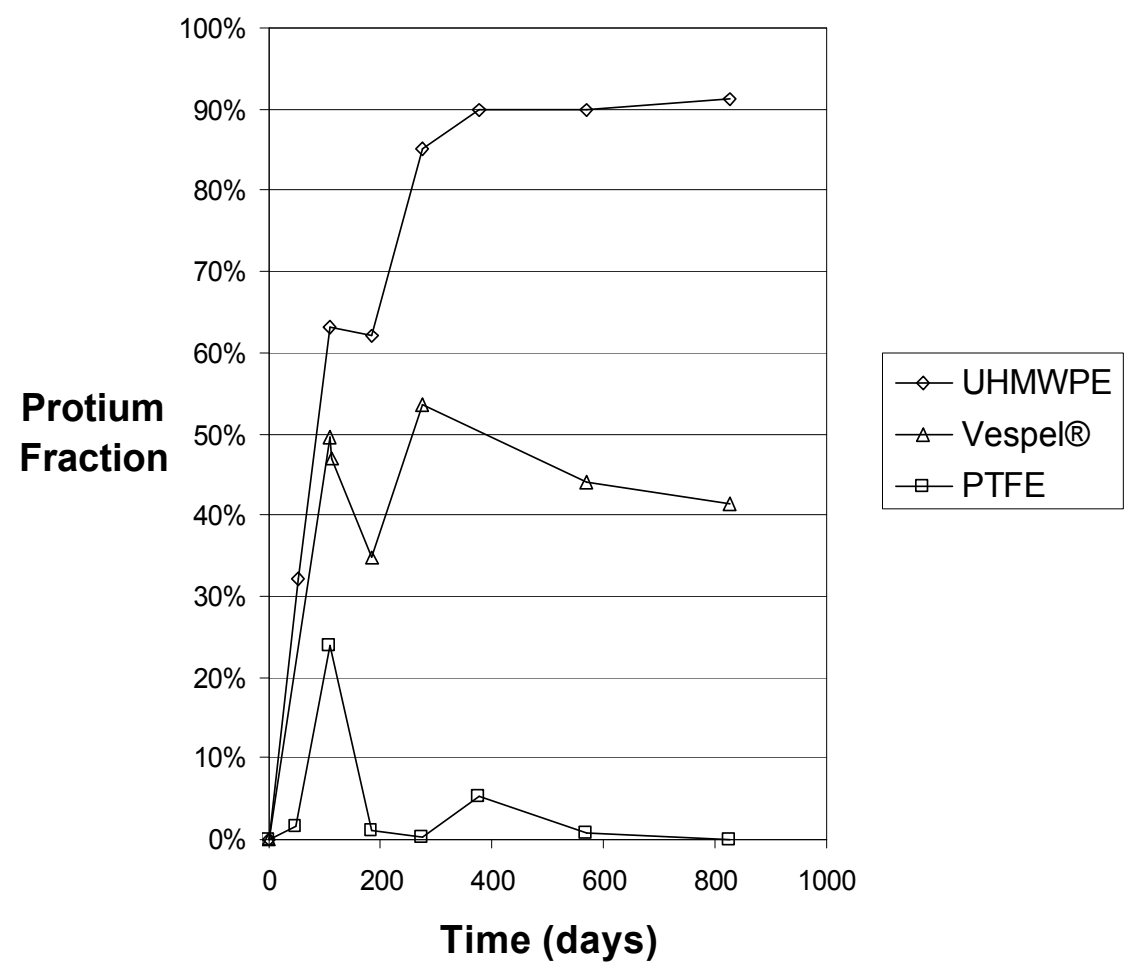

Fig. 2. Fraction of gas detected as protium, as function of exposure time. UHMW-PE, Vespel®, PTFE as marked. 


\section{Tritium Uptake in Polymers- per unit volume}

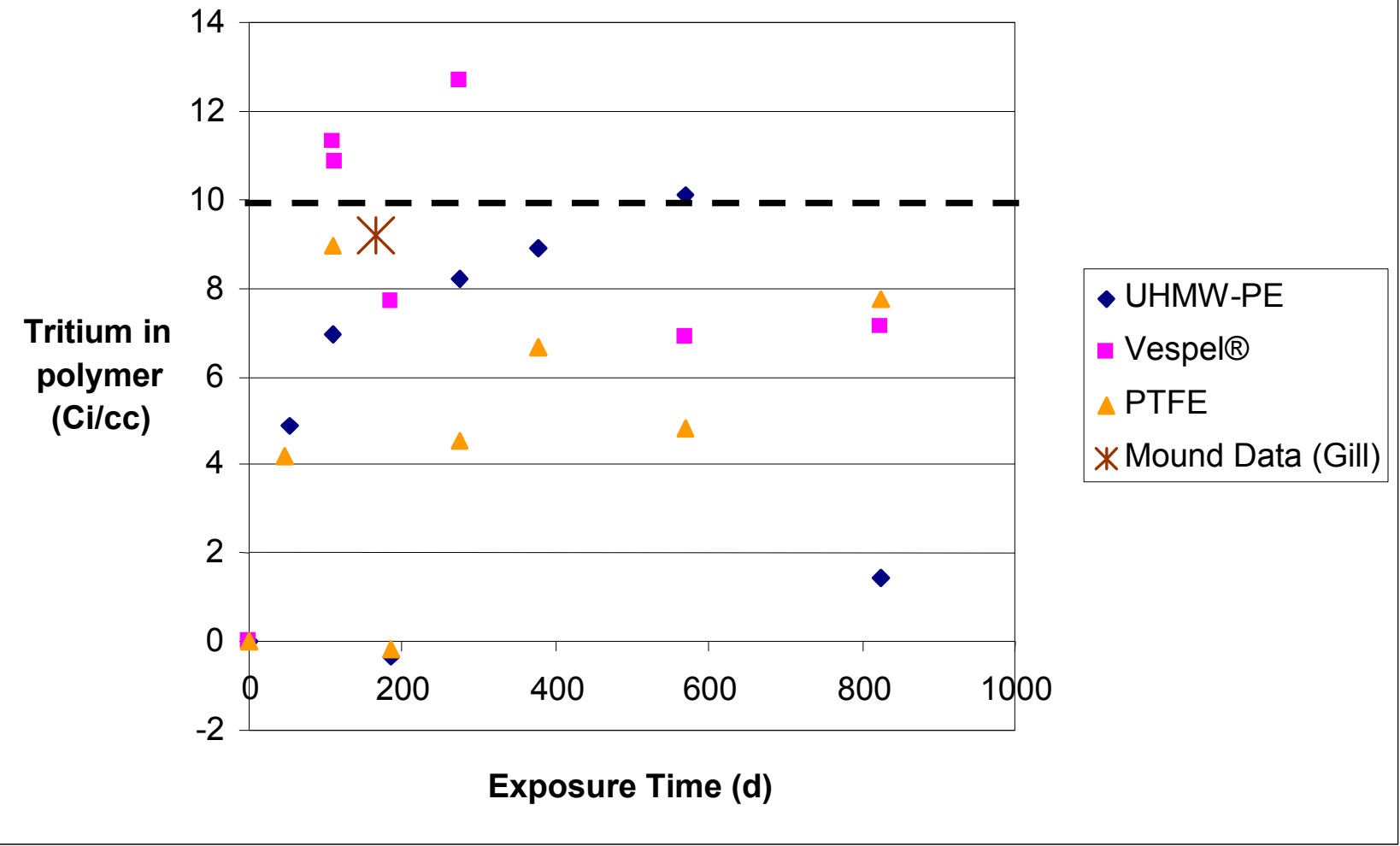

Figure 3. Curies tritium per unit volume residing in the various polymers as a function of exposure time. The currently used value for characterizing tritiated polymer components is 10 $\mathrm{Ci} / \mathrm{cc}$, indicated by the dotted line. 